\author{
Ahmad Ikhlasul Amal ${ }^{1}$ \\ Fakultas IImu Keperawatan, Universitas Islam Sultan Agung Semarang
}

\title{
ABSTRAK
}

\begin{abstract}
Latar Belakang: Kondisi perburukan akut didefinisikan sebagai suatu kondisi dimana terjadi progresi atas kesakitan yang kompleks. Progresi kesakitan terhadap pasien tersebut menyebabkan perpindahan status kondisi yang ditandai oleh tanda-tanda vital pasien yang mengalami abnormalitas. Perawat di bangsal penyakit dalam dan bedah tidak jarang menghadapi pasien dengan kondisi perburukan akut. Perawat dibangsal tersebut dtuntut memiliki kepercayaan diri saat memberikan pertolongan yang tepat pada kondisi perburukan akut. Metode: Penelitian ini merupakan penelitian deskriptif kuantitatif yang dilakukan di bangsal penyakit dalam rumah sakit islam sultan agung semarang. Jumlah responden yang digunakan dalam penelitian ini adalah 98 perawat, dengan teknik consecutive sampling. Hasil: Hasil penelitian menunjukkan bahwa diperoleh rerata tingkat kepercayaan diri perawat dalam menangani pasien kondisi perburukan akut di bangsal penyakit dalam adalah 3.03 sehingga dinyatakan responden memiliki tingkat kepercayaan diri yang sedang.Simpulan: Tingkat kepercayaan diri perawat dalam menangani pasien dengan kondisi perburukan akut perlu ditingkatkan untuk memberikan kualitas pelayanan yang terbaik.
\end{abstract}

Kata kunci: perawat, kepercayaan diri, perburukan akut.

\section{SELF-CONFIDENCE OF NURSES TO TREAT SUDDEN DETERIORATION PATIENTS IN MEDICAL WARDS}

\begin{abstract}
Background: Sudden deterioration defined as a condition in which a progression over a complex illness. Progression of pain to the patient causing displacement status characterized by the vital signs of patients who experienced abnormality. Nurses in medical and surgical ward almost everytime facing with patients with acute deterioration conditions. Nurses should have confidence when giving proper treatmen for acute patents deterioration. Methods: This study utilize quantitative descriptive research conducted in the hospital ward illness Islam Sultan Agung Semarang. The number of respondents that used in this study were 98 nurses, utilized consecutive sampling technique. Results: The results showed that the average level of confidence gained nurses treating patients in the ward conditions of acute deterioration in the disease is expressed 3.03. It is mean that respondents have moderate level of confidence. Conclusions: The level of confidence of nurses in treating patients with acute exacerbation of conditions needs to be improved to provide excellent service quality
\end{abstract}

Keywords: nurse, self-confidence, sudden deterioration.

Corresponding Author :

Ahmad Ikhlasul Amal ${ }^{1}$, Fakultas Ilmu Keperawatan Universitas Islam Sultan Agung, Jalan Raya Kaligawe Km 4, Semarang, Jawa Tengah, Indonesia, Kode pos 50112; e-mail ners.amal@gmail.com

\section{PENDAHULUAN}

Kondisi perburukan akut dapat terjadi pada berbagai waktu termasuk saat menjalani perawatan di bangsal. Pasien yang mengalami kondisi perburukan akut paling banyak ditemui pada kasus penyakit paru kronik dan serangan jantung. The National Confidential Enquiry menemukan bahwa 38\% kasus henti jantung dan resusitasi jantung paru dapat dicegah apabila perawat dapat mengenali kondisi perburukan akut lebih dini (Kate, Dagmar, \& Richard, 2008). 
Tanpa menyadari penyebabnya, tanda-tanda utama pada prognosis yang buruk dari seorang pasien adalah adanya reflek kompensasi fungsi pernafasan, jantung dan pembuluh darah serta saraf. Takipnea, takikardi, hipotensi dan perubahan tingkat esadaran adalah tanda yang menunjukkan pasien sedang mengalami kondisi perburukan akut (UK Resuscitation Council, 2006 dalam Jevon, 2010). Kondisi yang biasanya berhubungan dengan kegagalan dalam pertolongan selama kondisi akut adalah gagal nafas akut, gagal jantung akut, perubahan status kesadaran, arithmia, edema pulmo dan sepsis. Dalam studi tentang sistem penanggulangan gawat darurat terpadu, paling banyak kondisi kejadian tidak diinginkan diakibatkan karena serangan jantung dan penerimaan ke unit perawatan intensif yang tidak direncanakan (Daryl, Michael \& Rinaldo, 2011).

Pengukuran tanda vital oleh perawat sangatlah penting. Hal ini akan membantu perwat untuk mengenali tanda perburukan akut. Deteksi yang tepat dan pelaporan akan status perubahan tanda vital pasien sangat membantu dalam pemberian pertolongan yang berimbas pada luaran hasil yang dicapai. Elliot dan Conventtry (2012) menyatakan bahwa, terdapat delapan tanda vital yang harus diprioritaskan da;am pemantauan kondisi perburukan pasien. Diantaranya adalah suhhu, nadi, tekanan darah, frekuensi njafas, saturasi oksigen, nyeri, tingkat kesadaran dan luaran urin.

Bandura (1977) dalam Hart, Spiva, dan Mareno (2014) menjelaskan bahwa kepercayaan diri akan mempengaruhi pemilihan seorang individu untuk membuat dan merasakan mengenai tantangan perselisihan. Individu dengan tingkat kepercayaan diri yang tinggi akan dapat berusaha lebih kuat dan sukses dalam melaksanakan tugasnya.

Kepercayaan diri adalah sikap mental ynag dimiliki oleh seorang individu untuk menilai sesuatu, sehingga seseorang secara mandiri dapat melakukan sesuatu berdasarkan kemampuan yang dia miliki (Ghufron, 2011). Mnurut Walgito (2003), kepercayaan diri adalah basis untuk pengembangan karakter seperti kemandirian, kreatifitas, dan tanggung jawab sebagai karateristik yang dibutuhkan sesorang dalam menghadapai masalah di masa depan.

Berdasarkan latar belakang tersebut, maka perawat di bangsal penyaklit dalam sebagai seorang individu yang selalu menemui tantangan saat merawat pasien dengan kondisi perburukan akut, perlu diidentifikasi tingkat kepercayaan dirinya untuk mengetahui seberapa besar kepercayaan dirinya yang kemungkinan berimbas kepada pemberian pertolongan pasien perburukan akut.

\section{METODE}


Penelitian ini menggunakan desain deskriptif kuantitatif dimana bertujuan untuk mengidentifikasi gambaran tingkat kepercayaan diri perawat dalam menangani kondisi perburukan akut.

Responden dalam penelitian ini adalah perawat di bangsal penyakit dalam Rumah Sakit Islam Sultan Agung Semarangsebanyak 98 perawat. Teknik pengambilan sampel yang digunakan pada penelitian ini adalah consecutive sampling.

Instrumen yang digunakan pada penelitian ini adalah self-confidence scale yang diadaptasi dari Hicks, Coke and Li (2009) yang telah di lakukan uji validitas dan reliabilitas dengan cronbach alpha dari 0.93-0.96. Instrumen ini memiliki empat indikator utama diantaranya mengenali perubahan situasi, pemeriksaan fisik dasar, identifikasi intervensi keperawatan, dan evaluasi intervensi perawat dalam menangani situasi pasien dengan kondisi perburukan akut.

\section{HASIL DAN PEMBAHASAN}

Perawat di bangsal penyakit dalam menilai diri mereka dengan kategori sangat yakin dengan sedikit variasi dalam mean tertimbang. Tertimbang rata-rata tertinggi 3,17 diamati dalam dua indikator "Seberapa yakin Anda bahwa Anda tepat dapat melakukan intervensi untuk pasien dengan perubahan status mental?" Dan "Seberapa yakin Anda bahwa Anda dapat mengevaluasi efektivitas intervensi untuk pasien dengan sesak napas?".Ini berarti bahwa perawat sangat yakin dalam mengevaluasi intervensi yang telah mereka lakukan terhadap pasien dengan kondisi perburukan akut.

Peneliti mengamati bahwa perawat di bangsal penyakit dalam sebagian besar mengevaluasi sesak napas pada pasien dengan pasca henti jantung memanfaatkan prinsip manajemen airway dengan cara lihat dengar dan rasakan serta menggunakan auskultasi suara paru-paru. Tindakan tersebut sering dilakukan oleh perawat di bangsal penyakit dalam karena fungsi monitoring dalam setiap jam.

Menurut Hagberg (2007), seringnya perawat melakukan prosedur teknik manajemen jalan napas dapat meningkatkan retensi keterampilan monitoring dan evaluasi fungsi pernapasan pasien kondisi perburukan akut. Kepercayaan diri akan meningkat jika melaksanakan prosedur manajemen jalan napas dalam frekuensi yang sering.

Sebaliknya, rata-rata tertimbang terendah 2,78 diamati dalam indikator "Seberapa yakin Anda bahwa Anda dapat secara akurat menilai seorang individu dengan nyeri dada?". Hal ini membuktikan bahwa perawat menilai dirinya sendiri tidak percaya diri dalam melakukan 
penilaian fisik khususnya saat pasien perburukan akut mengalami nyeri dada. Hal ini mungkin disebabkan oleh perawat yang tergantung pada dokter untuk melakukan penilaian fisik toraks termasuk nyeri dada. Hal ini dapat membuat perawat tidak percaya diri dalam melakukan penilaian fisik.

Perilaku organisasi dan tradisi di kalangan tenaga medis adalah faktor-faktor yang mempengaruhi respon tenaga medis dalam perubahan kondisi pasien. Mereka sebagian besar lakukan berdasarkan pada tindakan sebelumnya saat menghadapi situasi perburukan akut (Cioffi, Salter, Wikes, Vonu-Boriceanu, \& Scott, 2006).

Namun, secara keseluruhan rata-rata dihitung 3.03, yang berarti bahwa perawat di bangsal penyakit dalam merasakan diri mereka sangat percaya diri untuk mengelola pasien dengan perburukan akut. Hal ini tampaknya merupakan penilaian yang berlebihan karena sebenarnya mereka mendapat kepercayaan diri mereka dari pengalaman selama merawat pasien dengan perburukan akut.

Temuan tersebut konsisten dengan studi Tahir, Dmitrieva, Lusignan, Vlymen, Chan, Golmohamad, Harris, Tomson, Thomas, dan Gallagher (2011) menyatakan bahwa praktisi medis memiliki keyakinan yang tinggi dalam mengelola pasien dengan masalah kardiovaskular termasuk serangan jantung akut dikarenakan mereka mendapat pengalaman selama bekerja di rumah sakit.

Hal ini juga didukung oleh studi lokal Widodo (2010), di mana ia menyebutkan bahwa selain mendapatkan keterampilan dari pengalaman, perawat perlu menghadiri pelatihan advance life support untuk meningkatkan pengetahuan dan sikap yang secara langsung akan berimbas kepada kepercayaan diri mereka untuk memberikan pertolongan pada pasien dengan perburukan akut khususny untuk kasus infark miokard akut.

\section{SIMPULAN DAN IMPLIKASI PENELITIAN}

Tingkat kepercayaan diri perawat dalam memangani pasien kondisi perburukan akut adalah berada ditingkatan sedang, dengan indikator pemberian intervensi saat pasien mengalami kondisi perburukan akut sebagai indikator yang paling menonjol. Namun indikator pemeriksaan fisik dasar pada pasien perburukan akut adalah indikator yang terendah yang dimiliki oleh perawat di bangsal penyakit dalam.

Peneliti menyarankan bagi perawat dibangsal penyakit dalam unruk mendapatkan pelatihan mengenai pengkajian dan monitoring yang tepat bagi pasien dengan kondisi perburukan akut, misalnya penggunaan nursing erly warning score di bangsal penyakit dalam untuk 
meningkatkan kepercayaan diri perawat dalam mengkaji pasien kondisi perburukan akut. Penelitain berkelanjutan lainnya tentang metode peningkatan kemampuan dan kepercayaan diri perawat dalam menangani kondisi perburukan akut juga perlu dilakukan.

\section{DAFTAR PUSTAKA}

Bandura, A. (1977). Self-Efficacy: Toward a unifying theory of behavior change. Psychological Review.84(2), 191-215. Retrieved from http://www.ncbi.nlm.nih.gov/pubmed/847061

Daryl, J., Michael, D., \& Rinaldo, J. (2011). Current concepts: rapid response teams. New England Journal of Public Health, 362(2), 139-146. Retrieved fromhttp://eresources.pnri.go.id:2057/docview/876930175?accountic

Hart, P.L., Spiva, L., \& Mareno, N. (2014). Psychometric properties of the clinical decisionmaking self-confidence scale. Journal of Nursing Measurement, 22(2), 312-322. doi: 10.1891/1061-3749.22.2.312

Hicks, F.D., Coke, L., \& Li, S. (2009). The effect of high-fidelity simulation on nursing students knowledge and performance: a pilot study. National Council of State Boards of Nursing. Retrieved from https://www.ncsbn.org/09 SimulationStudy Vol40 web with cover.pdf

Jevon, P. (2010). How to ensure patient observations lead to effective management of altered consciuseness. Nursing Times Deterioration Patient Supplement. 106(6), 23-24. http://www.nursingtimes.net/how-to-ensure-patient-observations-lead-to-effectivemanagement-of-aletered-consciousnes/5011735.article

Ghufron, M. N. (2011). Teori-teori psikologi. Yogyakarta: Ar-Ruzz Media.

Jevon, P. (2010). How to ensure patient observations lead to effective management of bradycardia. Nursing Times Deterioration Patient Supplement, 106(4), 17-19. Retrieved from http://www.nursingtimes.net/how-to-ensure-patient-observations-lead-toeffective-management-of-bradycardia/5011735.article

Jevon, P. (2010). How to ensure patient observations lead to prompt identification of tachypnea. Nursing Times Deterioration Patient Supplement, 106(2), 12-14. Retrieved from http://www.nursingtimes.net/how-to-ensure-patient-observations-lead-toprompt-identification-of-tachypnea/5011735.article

Walgito, B. (2003). Pengantar psikologi umum. Yogyakarta: ANDI 
